\title{
IS HUMAN CAPITAL ACCUMULATION A GROWTH DRIVER IN NIGERIA? AN EMPIRICAL INVESTIGATION
}

\author{
Hassan O. Ozekhome \\ Department of Economics and Statistics, University of Benin, Benin City, Nigeria. \\ hassanozeks1@gmail.com
}

\begin{abstract}
Accumulation of human capital is critical to sustained economic growth in the long run, since it facilitates the efficient absorption of new capital developments, improves the speed of adaptation of entrepreneurs and generates innovation necessary for sustained economic growth. It is against this premise this study investigate the human-capital accumulation growth-nexus in Nigeria. Employing a dynamic approach, involving test for unit roots, and cointegration, and finally, the Generalized Method of Moments (GMM) estimation techniques on annual time series data, covering the period 1981 to 2016, sourced from the World Bank Development Indicators (WDI) and Central Bank of Nigeria (CBN) Statistical Bulletin, the empirical findings reveal that human and physical capital accumulation significantly induce rapid and sustained economic growth in the long-run. The other variables- infrastructural development (measured by ICT infrastructure) and industrial output (a measure of industrialization) have positive but weak impacts on economic growth, on account of the weak infrastructural development, and low level of industrialization in Nigeria. Inflation rate (a measure of macroeconomic policy environment) on the other hand, is found to have a militating effect on economic growth. We recommend amongst others; sustained investments in human and physical capital accumulation, stable and coherent macroeconomic policies, particularly with respect to taming of domestic inflationary pressures, supportive institutional structures and aggressive industrialization-enhancing policies, in order to enhance sustained economic growth in Nigeria.
\end{abstract}

Keywords:, Human capital accumulation, Physical capital accumulation, Economic growth, Nigeria GMM.

JEL Classification: E24, F43, 047, C13.

\section{Introduction}

The growth-driving effect of human capital accumulation has long been established in the development literature. Following the celebrated works of Romer (1986) and Lucas (1988), which accorded human capital accumulation a critical ingredient in the explanation of growth process, increased studies have spawn the empirical literature seeking to examine the human capital accumulation-growth nexus. The increased empirical interest has partly been spurred by increased availability of data on human capital (school enrolment ratio), allowing researchers examined the link in a coherent, intuitive and more rigorous analytical framework. While Romer $(1986,1990)$ shows that human capital accumulation favours the generation and absorption of technology, permitting innovation, and thereby stimulating growth, Lucas (1988) emphasized that the accumulation of human capital is responsible for sustained growth, and that education is the main channel through which the accumulation of human capital is made possible. In the same vein, the contribution of Mankiw et al (1992) which incorporates human capital into the Solow's model, as an additional growth explaining 
factor in the long term, further motivated interests in the way human capital explains growth (Bouznit, et al., 2015).

A number of other studies have considered the effects of total factor productivity, technological innovation, knowledge creation and diffusion, in explaining growth empirics in different countries (Benhabib and Spiegel, 1991, 1994; Maw-Lin, et al.1994; Hanushek, 2013). These studies have consistently shown that sustained physical and human capital accumulation are highly growth-inducing. Other studies have provided empirical evidence that human capital development will accelerate the pace of physical capital accumulation through learning by doing. Rodrick (1996) for instance, argues that the growth success story in South-Korea could be explained by a well-educated labor force that enhanced productivity of private investment, brought about by considerable investments in research and higher education.

Nigeria is an oil-dependent nation, with a growing population of about $3.2 \%$ annually. Its GDP is put at $\$ 422$ billion at constant purchasing power (World Bank, 2016). Its school enrolment ratio (a measure of human capital) is currently put at below $50 \%$. Since capital accumulation is believed to be the engine of growth, there is need to increase her human capital accumulation to accelerate economic growth, and in particular, to diversify the productive base of the economy from oil, given that the acquisition of knowledge, skills, innovation and technology, accompanied by institutional and economic reforms are capable of generating sustained economic growth than dependence on natural resources (Ozekhome, 2017). In fact, the capacity of an economy to exploits its natural resources and to initiate and sustain long-term economic growth is dependent on, among other things, the ingenuity and the managerial and technical expertise of its people (Todaro and Smith, 2011: 72, cited in Ozekhome, 2017).

In recent years, the Nigeria government recognizing that human capital is a principal growth-driver, has given attention to various human capital development programme through increased educational funding, and various school initiatives and strategies aimed at increasing school enrolment ratio. These include tuition free primary (elementary) education, free distribution of primary school educational materials, various school feeding programme, e.t.c and tuition free secondary education in some states of the federation (Lagos and Edo). Others include; establishment of various skill acquisition training schools and centers, foreign educational scholarships and trainings, increased funding to the education and health sectors, and other institutional set-ups to monitor and combat the proliferation of diseases in order to enhance human capital development and its efficiency. However, these efforts have not produced the desired effect due to poor prioritization, weak implementation, corruption and other restraining factors.

There is dearth of empirical evidence on the role of human capital accumulation on growth in Nigeria, as most of the studies have used a rather too-aggregative approach; by investigating the impact of government expenditure on education as a proxy for human capital on growth. By this approach, these studies (see Ighodaro and Oriakhi, 2010; Adesoye, et al. 2010) only examined the public expenditure aspect of educational expenditure on growth, neglecting the critical aspect of school enrolment ratio as a better proxy for human capital. Increased educational funding if not efficiently channeled with result-oriented strategies may not increase the school enrolment ratio and educational attainment. This study attempts to bridge this perceived gap, by using an appropriate measure for human capital accumulation on growth in Nigeria.

In particular, given the fact that the accumulation of human capital is critical to achieving the matchless drive to accelerated and sustained economic growth in Nigeria, via the enhancement of the productive work force capacity, and, the explicit recognition that significant growth and development cannot be achieved, without a well-trained, educated, productive and managerially-inclined labour force, there is greater need to reinvestigate the 
human-capital accumulation-growth nexus in Nigeria. It is this reason that has made this study imperative.

In the light of this, the following research questions are raised in this study:

(i) What is the link between human capital accumulation and economic growth in Nigeria?

(ii) Does the accumulation of human capital significantly drive economic growth in Nigeria in the long run?

\section{Review of Literature}

\subsection{Theoretical Issues}

Romer (1990) through endogenous growth model has demonstrated that sustained human capital accumulation induces marginal returns to investments, with positive spillovers, permitting increasing returns to scale in aggregate production, and through technological diffusion, enhances growth. According to Romer $(1986,1990)$, investments in human capital (education), infrastructure, research, and development (R\&D) stimulates growth. The model gives an explicit recognition to sustained investment in human capital accumulation, which permits diffusion of knowledge or knowledge spillovers, technology efficiency and productivity growth, which have the capacity to stimulate growth. Through 'learning by doing', the model further demonstrates the high growth-generating capacity of human capital accumulation. In general, the model demonstrates that capital accumulation encompassing investments in physical and human capital is critical to rapid and sustained growth path. In the endogenous growth model, the possibility thus, exist that sustained investments in physical and human capital can generate external economies, positive growth-enhancing spillovers and productivity improvements that exceed private gains by an amount sufficient to offset diminishing returns (Ozekhome, 2016).

Lucas (1988) further argued that increased investment and improvements in innovations and technical progress arising from human capital development can lead to increase productivity and competitiveness, which trigger a further growth. The contributions of Mankiw et al (1992), which incorporate human capital into the original Solow's model as an additional factor to explain economic growth in the long term, further expanded the human capital-growth nexus. By this, the model endogenized human capital as a' growth explaining factor. Rodrick (1996) relying on the endogenous growth framework, further emphasized that better educated workforce and combination of learning-by doing, have the capacity to enhance the productivity of private investment, which in turn triggers growth. In general, the endogenous growth model accorded prime role to deliberate or intentional investment in physical and human capital in the growth process of countries. Romer (1986) using this growth model, further demonstrates that not only that sustained investments in human and physical capital stimulates growth, but that through knowledge spillovers, (positive externalities), a firm's increase in investment in human and physical capital, will, enable the firm move to a higher production function, as well as that of the production functions of neighboring firms, thereby permitting economies of scale in research, development and innovation, which leads to higher growth path.

\subsection{Empirical Review}

A number of empirical studies have examined the impact of human capital on economic growth. These studies are briefly examined.

Lucas (1988) and Mankiw et al. (1992) using copious empirical evidences argue that human capital accumulation promotes sustained economic growth. Benhabib and Spegiel (1994) investigate the role of human capital in economic development, using aggregate cross-country evidence. The findings show that human capital is positively and significantly 
related to growth. The authors argue that human capital increases the capacity of a country to develop its own innovations and its ability to develop other technologies critical to rapid and sustained economic growth. Romer $(1986,1990)$ using the endogenous growth model concludes that human capital generates innovation and through technology spillovers, stimulates growth. This finding is corroborated by the findings of Maw- Lin et al. (1994) and Rodrik (1996).

Kwack and Lee (2006) investigate the role of research and development (R\&D) fostered by human capital accumulation in the analysis of the Korean's growth experience. Employing human capita- based growth models, with demography, the findings show that human capital development and R\&D positively and significantly influenced the spectacular growth performance recorded. The authors conclude that the differential rates of growth across countries can be explained by varying degrees of human capital stock.

Harvie and Pahlavani (2007) examine the sources of economic growth in South-Korea. Employing the technique of Auto Regressive Distributed Lag (ARDL), in the presence of structural breaks, the empirical results show that human capital, via higher education is a critical explanatory factor to the growth miracle of South-Korea. The study also emphasized the critical role of human capital in efficiently absorbing new capital development, which induces rapid growth in South-Korea.

Maksymenko and Rabbani (2011) investigate the relationship between economic reforms, human capital and economic growth in India and South-Korea. Employing cointegration analysis, the empirical results reveal that human capital accumulation stimulates economic growth. They concluded that higher education contributed significantly in no small measure to South- Korea's growth, particularly in the in the efficient absorption of new capital developments. Barro and Lee (2013) find evidence, that, an abundance of well-educated people is positively associated with higher level of labour productivity and growth.

Awad, Halid and Yussof (2013) investigate the impact of human capital on economic growth, using evidence from selected Arab countries. The empirical findings reveal that human capital has a positive and significant effect on the growth of Arab countries.

Mehrara and Musai (2015) investigate the causality between education and economic GDP growth in Asian countries. Employing various econometric techniques, including the causality tests, the findings show that education leads to higher economic growth. According to the authors, education allows to spillovers effects, improves the speed of adaptation of entrepreneurs to imbalance and boosts research productivity. They conclude that increased investment in human capital is necessary to move any economy to higher growth path.

On research studies relating to Africa, Gyimah-Brempong (2011), Mijiyiwa (2013) and Ayanwu (2014) find evidence that human capital is an important factor affecting growth. These studies show evidences of the critical role of the human capital in the growth process of African countries.

Some studies however report evidence of weak correlation between education and growth or weak causality from education to growth. Levine and Renalt (1992) and Benhabib and Spiegel (1994), are notable in this direction. Other studies (see De La Fuente and Domenech, 2006 and Cohen and Soto, cited in Bouznit et al., 2015) have shown evidence of no correlation between education and growth. The lack of significance of these relationships was however due, according to some authors, on poor quality of data, measure of human capital used and incongruent data series.

From the fairly large volume of literature, it appears that the findings of empirical studies on the effects of human capital on growth are rather mixed and non-conclusive for the developing countries. In addition, the relationship between growth and human capital is rarely investigated at country-case level, particularly, Nigeria, hence, warranting further empirical investigations. 


\section{Empirical Methodology}

\subsection{Theoretical Framework and Model Specification}

This study is based on the endogenous growth model. The motivation for the endogenous growth model stems from its explicit ability to explain the intrinsic characteristics of economies that cause them to grow over extended period of time. The most interesting aspect of endogenous growth models is that it helps to explain the disparities in growth rate across countries, arising from differential rates of capital accumulation. The potentially high rates of growth are, according to the model, due to sustained investments in human capital (education), infrastructure, research, and development (R\&D).

The general endogenous production function is

$$
\text { GDP }=A K ;{ }_{i}^{\infty} L^{1-\infty}{ }_{i} K^{B}
$$

Where:

GDP = GDP per capita at time (a measure of economic growth).

$A=$ Total factor productivity- a measure of efficiency of factor inputs

$\mathrm{K}=$ Capital stock (which is decomposed to into human and physical capital)

$\mathrm{L}=$ Labour.

$\alpha$ and $\beta$, represents the elasticity of output with respect to capital and labour, respectively.

For simplicity, we assume symmetry across industries, so that each industry uses the same level of capital and labour. Then, the aggregate production function becomes:

$$
\mathrm{GDP}=\mathrm{AK}^{\propto} \mathrm{L}^{\mathrm{B}}
$$

The model in equation (1) and (2) are endogenous growth models, since the residual component, $\mathrm{A}$, which is a measure of technological progress and human capital accumulation is endogenized; thus implying that technological knowledge and the accumulation of human capital are incorporated not as exogenous growth- generating factors but explaining the growth process itself (Udah, 2010, cited in Ozekhome, 2016). In empirical applications, the endogenous growth model takes account the role of investments in human and physical capital, and other policy variables such as inflation, as critical ingredients of growth. Incorporating these relevant variables and adding industrial output to the augmented model, yields the following specification for the determinants of economic growth in Nigeria.

$$
\text { GRGDP=f( INV, SCHL, INFR, INF, INDP). }
$$

Equation (3) shows that potentially, growth of real GDP (GRGDP) is determined by, INV, SCHL, INFR, INF and INDP, which form a plausible relationship in order to estimate the above equation.

In empirical specification, the model (1) above is re-specified as:

Where:

$$
\text { GRGDP }=\alpha_{0}+\alpha_{1} \text { INV }+\alpha_{2} S C H+\alpha_{3} \text { INFR }+\alpha_{4} \text { INF }+\alpha_{5} \text { INDP }+\mu \ldots . .
$$

GRGDPG = Growth Rate of Real Gross Domestic Product (a measure of real economic growth);

INV= real gross fixed capital formation as percentage of GDP (a measure of growth rate of physical capital stock)

$\mathrm{SCHL}=$ enrolment in secondary institutions as a measure of human capital accumulation INFR= Infrastructure (i.e ICT infrastructure- measured as the number of telephone main lines and mobile subscribers per 1000 persons)

$\mathrm{INF}=$ inflation rate- measured as the growth rate (in percent) of the consumer price index(used to capture the macroeconomic policy environment).

The apriori expectations are $\left(\alpha_{1}, \alpha_{2}, \alpha_{3} \alpha_{5}\right)>0$; and $\left(\alpha_{4}\right)<0 . \alpha_{0}-\alpha_{5}$ are parameters to be estimated, and $\varepsilon_{t}$ is the error term. 
From apriori expectation, gross capital formation, human capital, infrastructure and industrial production are expected to have positive impacts on economic growth, while the coefficient of inflation is expected to have a negative relationship with economic growth. The higher the level of domestic investment, the more rapid will be the rate of economic growth, since investment increases the capital stock, and stimulate aggregate demand. An improvement in human capital (reflected in human capital accumulation) enhances growth, through the channels of increased productivity of the work force, technical and managerial enterprise and innovation which it induces. Thus, the higher the quality of human capital, the higher the rate of economic growth. The higher the level of infrastructural development, the higher the growth rate, since infrastructure (proxied by Information communication technology) facilitates technological and industrial development, and hence, growth. Increased industrial production stimulates economic growth. Hence, the higher the level of industrial production, the faster the rate of economic growth. Inflation is theoretically posited to have an inverse relationship with economic growth. This is because evidence suggests that macroeconomic stability is crucial for long-term growth, as no country has achieved sustained high growth in a persistently high inflation environment (i.e macroeconomic instability). Accelerating rates of inflation has a destabilizing effect on economic growth through its dampening impact on savings, investment and its increasing uncertainty syndrome (Ozekhome, 2016).

\subsection{Data Sources and Estimation Technique}

The data used for the study are annual time series data covering the period 1981-2016 and were obtained from various sources to include, World Bank World Development Indicators and Central Bank of Nigeria Statistical Bulletin. The period is specifically chosen due to the increased policy attention to human capital accumulation, in recent times by the Nigerian government from an era of less policy focus and attention. A sequential empirical analytical approach is adopted in this study, in order to make the study, robust and dynamic. First, a preliminary statistical examination using summary (descriptive) statistics of the variables is done in order to understand their initial characterization. Next the unit root test of stationarity is conducted to examine the stationarity status of the time series variable. Next, the test of cointegration is carried out to examine the existence of long-run relationship between human capital accumulation and economic growth in Nigeria. Finally, the fact that human and physical capital are often determined jointly, analyzing the accumulation of one factor often requires the inclusion of the other in the system. This may results to potential endogeneity problem in the system, making the OLS estimates biased and inconsistent. To avoid these problems, an instrumental variable technique- the Generalized Method of Moments (GMM) is adopted for the econometric estimation. The estimation technique is important to control for the biases resulting from simultaneous or reverse causation and omission bias. All data in this study are in log form. The summary (descriptive statistics) is presented in table 1.

\section{Empirical Results and Analysis}

\subsection{Descriptive Statistics}

Table 1 presents the summary statistics of the sample data on the variables used for the analysis. The descriptive statistics shows that the average growth rate of real GDP over the period is 4.7 percent, with a median value of 4.9 percent. The maximum and minimum values are 8.5 percent and -1.5 percent respectively- an indication that growth rate in real GDP over the period has been characterized by marked disparity, implying that the rate of growth was high in some of the years, while it was abysmally lower than the observed average in other years. This wide dispersion is confirmed by the relatively high standard deviation value of 4.7 percent. Apparently, real GDP growth has been generally unstable in the country. Gross capital formation (a measure of domestic investment/physical capital) 
has a mean value of 39.4 percent, and a median value of 38.7 percent. Its corresponding maximum and minimum values are 62.3 percent and 2.5 percent, respectively. Secondary school enrolment ratio (a measure of human capital) has a mean value of 49.5 percent, and a median value of 48.9 percent. Its maximum and minimum values are 72.1 percent and 13.2 percent, respectively. Infrastructure (proxied by information communication technology) has a mean value of 54.2, median value of 49.4 percent, and a standard deviation value of 4.70 percent. Its maximum and minimum values are 80.3 percent and 4.8 percent, respectively. Inflation has a mean value of 20.2 percent growth rate, with maximum and minimum values of 72.8 percent and 4.7 percent respectively. Its standard deviation of 5.2 percent combine with a kurtosis value of -1.45 is a clear indication of inflation variability over the period of study. Invariably, inflation growth rate has not only been rising, but generally unstable, deviating from the mean observed value or equilibrium value over time. Industrial production has a mean value of 8.2 percent, with a median value of 7.9 percent. Its maximum and minimum values are 25.3 percent and -1.7 percent, respectively. Overall, the skewness value for growth rate of real GDP of 0.22 , is low suggesting that the growth series were centered on the mean value. The Jarque-Bera value of 12.7 is significant at the 1 percent level, indicating that the hypothesis of normality in the distribution cannot be accepted. This implies that the data series may have endogeneity issues. This therefore necessitates adoption of a dynamic GMM estimator which is capable of controlling the joint endogeneity effect of most of the explanatory variables with economic growth, and, thus to control for the biases resulting from simultaneous or reverse causation.

Table 1: Descriptive Statistics

\begin{tabular}{|l|l|l|l|l|l|l|l|l|}
\hline & Mean & Median & Max. & Min. & Std. Dev. & Skew & Kurt. & J-B \\
\hline$R G D P$ & 4.7 & 4.9 & 8.5 & -1.5 & 4.4 & 0.72 & 2.2 & 12.7 \\
\hline$I N V$ & 39.4 & 39.4 & 62.3 & 2.5 & 3.7 & 2.8 & 3.4 & 10.2 \\
\hline$S C H L$ & 49.5 & 48.9 & 72.1 & 13.2 & 3.7 & 1.8 & 2.2 & 9.5 \\
\hline$I N F R$ & 54.2 & 49.98 & 80.3 & 6.2 & 4.8 & 1.7 & 2.6 & 7.1 \\
\hline$I N F$ & 20.2 & 19.8 & 72.8 & 4.7 & 5.2 & -1.3 & -1.5 & 8.2 \\
\hline INDP & 8.2 & 7.9 & 25.3 & -1.7 & 3.7 & -1.5 & 4.5 & 6.2 \\
\hline
\end{tabular}

Source: Author's computation (2017)

\subsection{Unit Root Test}

In order to examine the stationarity of the time series properties used in this study, the unit root test is conducted, using the Augmented Dickey Fuller (ADF) test. The rationale for stationarity test borders on the fact that a non-stationary time series is not possible to generalize to other time periods apart from the present. This makes forecasting based on such time series to be of little practical value. Moreover, regression of a non-stationary time series on another non-stationary time series may produce spurious and inconsistent estimates. The results of the unit root test are given in levels and first difference in table 2:

Table 2: Unit Root Test

\begin{tabular}{|l|l|l|l|l|}
\hline Variable & $\begin{array}{l}\text { ADF Statistic } \\
\text { (in Levels) }\end{array}$ & $\begin{array}{l}\text { ADF Test Statistic (in } \\
\text { First Difference) }\end{array}$ & $\begin{array}{l}\text { Order of } \\
\text { Integration }\end{array}$ & Remark \\
\hline GRGDP & -1.9902 & $-5.3352^{\star *}$ & $\mathrm{I}(1)$ & Stationary \\
\hline INV & -1.4674 & $-5.9642^{* \star *}$ & $\mathrm{I}(1)$ & " \\
\hline SCH & -1.8012 & $-6.4051^{* * *}$ & $\mathrm{I}(1)$ & " \\
\hline INFR & -0.9984 & $-5.4424^{\star *}$ & $\mathrm{I}(1)$ & " \\
\hline NF & -1.6652 & $-4.8872^{* \star}$ & $\mathrm{I}(1)$ & " \\
\hline NDP & -1.3052 & $-5.1154^{\star *}$ & $\mathrm{I}(1)$ & " \\
\hline
\end{tabular}

$\left.{ }^{*}{ }^{* *}\right)$ denotes significance at $5 \%(1 \%)$ level 
A cursory examination of the unit root test results using the ADF test statistic indicate for all the variables, the null hypothesis of no unit root could not be rejected, implying that the variables were non-stationary at levels. However, after first differences, the variables became stationary. This implies that the variables are difference-stationary, attaining stationary after first difference. They are thus integrated of order one I (1).

\subsection{Test of Cointegration}

Having established that the series in the analysis are integrated of order I(1), we move on to determine if they are cointegrated. Co-integrationof a vector variable implies that the number of unit roots in the system is less than the number of units in the corresponding univariate series (Engle and Granger, 1987).Cointegration is a test of long-run equilibrium relationship between a given dependent variable and its explanatory variables. The Johansen Cointegration method is used for this analysis because the study involves the use of multivariate estimations. The results from the multivariate cointegration test are presented in Table 3 below. As can be seen from the table, both the $\lambda$-max and the trace test statistics indicate that there is at least four significant cointegrating vectors among the variables, since the hypothesis of no cointegrating vector $(r=0)$ is to be rejected. Apparently, the number of cointegrating relations or vectors (indicated by $r$ ) is at least four. The implication of this is that a long run equilibrium relationship exists between economic growth and human capital accumulation in Nigeria.

Table 3: Johansen Multivariate Cointegration Tests Results.

\begin{tabular}{|c|c|c|c|c|c|c|}
\hline \multicolumn{3}{|l|}{ Trace Test } & \multicolumn{3}{|c|}{ Maximum Eigenvalue Test } & \\
\hline $\begin{array}{l}\text { Null } \\
\text { Hypothesis }\end{array}$ & $\begin{array}{l}\text { Test } \\
\text { Statistic }\end{array}$ & $\begin{array}{l}\text { Critical } \\
\text { Value }\end{array}$ & $\begin{array}{l}\text { Null } \\
\text { Hypothesis }\end{array}$ & $\begin{array}{l}\text { Test } \\
\text { Statistic }\end{array}$ & $\begin{array}{l}\text { Critical } \\
\text { Value }\end{array}$ & $\begin{array}{l}\text { Hypothesized } \\
\text { No of } C E(s)\end{array}$ \\
\hline$r=0^{*}$ & 99.8 & 76.4 & $r=0^{*}$ & 62.6 & 42.65 & None $^{* *}$ \\
\hline$r \leq 1$ * & 60.3 & 45.2 & $r=1^{*}$ & 34.4 & 27.83 & At most $1^{\text {** }}$ \\
\hline$r \leq 2^{*}$ & 37.1 & 15.3 & $r=2^{*}$ & 14.2 & 13.13 & At most $2^{* *}$ \\
\hline$r \leq 3^{*}$ & 15.3 & 4.7 & $r=3^{*}$ & 3.8 & 3.26 & At most $3^{\star *}$ \\
\hline$r \leq 4^{*}$ & 2.9 & 0.85 & $r=4^{*}$ & 1.7 & 0.75 & At most $4^{\star *}$ \\
\hline$r \leq 5^{*}$ & 0.017 & 0.019 & $r=5^{\star}$ & 0.017 & 0.019 & At most 5 \\
\hline
\end{tabular}

${ }^{*}\left({ }^{\star *}\right)$ denotes rejection of the hypothesis at $5 \%(1 \%)$ significance level.

\subsection{Analysis of Generalized Method of Moments (GMM) results}

The result of the Generalized Method of Moment (GMM) is presented in table 4 below, and subsequently analyzed. Economic growth rate is instrumented by its first lag (lagged growth rate) to capture previous growth levels on current economic growth rate (i.e. growth persistence).

Table 4: Results from GMM. Dependent Variable: GRGDP

\begin{tabular}{|l|l|l|l|}
\hline Variables & Estimated Coefficient & t-statistics & Prob \\
\hline C & 0.1106 & 1.4015 & 0.14 \\
\hline Lagged GRGDP & 0.0422 & $1.9342^{*}$ & 0.06 \\
\hline LnINV & 0.3253 & $3.3320^{* \star *}$ & 0.001 \\
\hline LnSCH & 0.2272 & $2.7781^{* \star *}$ & 0.01 \\
\hline INFR & 0.1722 & $1.8740^{*}$ & 0.06 \\
\hline LnINF & -0.0920 & $-2.1731^{* *}$ & 0.03 \\
\hline LnINDP & 0.1814 & 1.5304 & 0.13 \\
\hline
\end{tabular}




\begin{tabular}{|l|l|l|l|}
\hline Variables & Estimated Coefficient & t-statistics & Prob \\
\hline $\mathrm{R}^{2}=0.921$ & \\
\hline $\mathrm{DW}=1.87 ; \mathrm{J}$-stat $=1.73$ & \\
\hline
\end{tabular}

*** Statistical significance at the $1 \%$ leve;

** Statistical significance at the $5 \%$ level;

* Statistical significance at the $10 \%$ level

An examination of the results reported in Table 4 show good diagnostic statistics. The $\mathrm{R}$-squared value of 0.921 is impressive and shows that over 92 percent of the systematic variations in economic growth is explained by the independent variables. The D.W. statistic of 1.87 is reasonably close to 2 , an indication of the absence of serial correlation in the estimates. The J-statistic fails the significance test at the 5 percent level, indicating that we cannot reject the null hypothesis that the over-identifying restrictions are equal zero. Apparently the growth equation along with the selected instruments passes the identification tests. Consequently, we cannot reject the specification of model, since it is well specified and the instruments seem to be appropriate; an implication that the model can be used for structural and robust policy analysis.

All the explanatory all variables have the correct signs. Since all the data are in log form, the coefficients are elasticities. All variables have the correct signs. Lagged growth rate of real GDP has the correct positive sign and is significant at the 10 percent level. This implies some level of growth persistence in Nigeria- an indication that previous growth rate could serve a $s$ as a spring board for attaining future higher growth, particularly in terms of macroeconomic policy direction. In line with the estimates, a 10 percent increase in previous economic growth, will stimulate future economic in the succeeding year by 0.4 percent. The coefficient of domestic investment (real gross domestic capital formation) has the expected positive sign and is significant at the 1 percent. Thus, increase domestic investment will inevitably spur economic growth in Nigeria through aggregate demand effect, and increased productivity of capital stock. The finding is in line with the findings of Benhabib and Spiegel (1991) and Ozekhome (2016). Its elasticity coefficient shows that a 10 percent rise in physical capital accumulation will induce economic growth in Nigeria by 3.3 percent.

The coefficient of human capital has the expected positive sign and passes the significance test at the 1 percent level. This implies that, increase human capital accumulation has the capacity to promote and sustain economic growth in the long-run, particularly through the channels of productivity growth, innovation, absorption of advanced technology, and adaptation of entrepreneurial and managerial efficiency, exemplified in the endogenous growth model. The result corroborates the finding of Maksymenko and Rabbani (2011), Bouznit et al (2015) and Ozekhome (2016). Its elasticity coefficient indicates that that a 10 percent increase in human capital accumulation will on the average induce economic growth in Nigeria by 2.3 percent. Infrastructure (proxied by information technology- ICT) has the expected positive sign but is not statistically significant at the 5 percent level. This could be due to the low level of infrastructural development in Nigeria. Since the t-value of its coefficient is greater than unity, we may infer that infrastructure development facilitates economic growth, but its effect is rather weak in Nigeria. This finding is corroborated by the findings of Ozekhome (2016). Its elasticity coefficient shows that a 10 percent increase in infrastructural development will spur economic growth by 1.7 percent in Nigeria. Inflation is significant at the 5 percent level, and has the expected negative sign. Thus, high inflation rates militate against rapid economic growth. This destabilizing effect of inflation on growth is also buttressed by the findings of Park (2012) and Ozekhome (2016). Its elasticity coefficient indicates that a 10 percent rise in the rate of inflation will dampen economic growth in Nigeria by 0.9 percent. 
The level of industrialization (as measured by industrial output) has the expected positive sign, but it is not statistically significant at the 5 percent level. This could be due to the low level of industrialization and industrial technology needed to propel rapid industrialization in Nigeria. Since the t-value of its coefficient is greater than unity, we may infer that industrial output facilitates rapid economic growth, but its effect is rather weak. Its elasticity coefficient of implies that 10 percent increase in industrial development will induce economic growth in the Nigeria by approximately 1.8 percent.

\section{Conclusion}

Human capital accumulation is a significant growth driver, as it generates critical knowledge, capabilities, skills and innovation that are relevant for rapid and sustained economic growth in the long run. It facilitates the absorption of technology, improves the speed of adaptation of managerial enterprise, boosts research productivity and thus, stimulates growth. This study has examined the impact of human capital accumulation on economic growth in Nigeria, over the period 1981-2016. The choice of the estimation period was based on the increased policy attention of the Nigerian government to human capital as a significant growth-driver, via increased educational funding, and various policies and strategies aimed at increasing school enrolment ratio and other institutional set-ups to increase human capital stock during the period, making it worth studying.

Employing sequential analyses, involving preliminary statistical examination of the sample data using descriptive statistics, unit root test of stationarity, and cointegration (to investigate the existence of long-run-relationship between human capital accumulation and economic growth) in Nigeria, and finally the GMM estimation approach, the empirical findings revealed a long run relationship between human capital accumulation and economic growth in Nigeria. Estimates from the GMM show that gross domestic capital formation (a measure of physical capital stock), human capital, and inflation (a proxy for macroeconomic environment) are significant variables influencing economic growth in Nigeria. In particular, human capital accumulation is found to have be significant in sustaining economic growth in the long run in Nigeria. The impact of infrastructural development (proxied by ICT infrastructure) and industrial production on economic growth are positive but weak, perceivably due to the weak infrastructural development, low level of industrialization, and poor technological development and innovation in Nigeria. Based on the empirical findings of this study, there is greater need for increased and sustained investments in human and physical capital accumulation, in order to increase the capacity to adopt and absorb technology, generate innovation and propel efficient managerial enterprise necessary for rapid and sustained economic growth in Nigeria in the long-run. This is because sustained investments in human and physical capital have the capacity to generate massive positive spillover effects, increase the aggregate stock of capital, and through increased productivity, generate rapid and sustained economic growth in the long run. In addition, greater level of investments in R\&D should be encouraged. Importantly, government should increase her investments in the provision of sustainable public infrastructure that are critical to growth. Very importantly, sound and stable macroeconomic policies, particularly with respect to low level of inflation, supporting institutional structures, and aggressive industrialization-promoting policies are imperative for driving economic growth to sustained levels.

\section{References}

Adesoye, A., Maku, O. and Atanda, A. 2010. Dynamic Analysis of Government Spending and economic growth in Nigeria. Business and Economics Journal, 24-37. 
Ayanwu, J. C. 2014. Factors Affecting Economic Growth in Africa: Are there any Lessons from China?'. African Development Review, 26(3), pp. 468-493.

Barro, R. J. and Lee, J. W. 2013. A New Data Set of Educational Attainment in the World. Working Paper, Department of Economics, New York University.

Benhabib, J. and Spiegel, M. M. 1991. Growth Accounting with Physical and Human Capital Accumulation. Working Paper, Department of Economics, New York University.

Benhabib, J. and Spiegel, M. M. 1994. The Role of Human Capital in Economic Development: Aggregate from Cross-Country Data. Journal of Monetary Economics, 34, pp. 143-173.

Bouznit, M., Yassine, M. Ferfera,M. Y. and Pablo-Romero, M. D. P. 2015.The Slow Economic Growth in Algeria: A Comparative Study with Respect to South Korea. African Development Review, 27(4), pp. 377-391.

Cohen, D. and Soto, M. 2007. Growth and Human Capital: Good Data, Good Results. Journal of Economic Growth, 12(1), pp. 51-76.

De la Fuente, A. Domenech, R. 2006. Human Capital in Growth Regressions: How Much Differences Does Data Quality Make? Journal of the European Economic Association, 1(3), pp. 1-36.

Engle, R., Granger, C. 1987. Cointegration and Error-correction: Representation, Estimation, and testing. Econometrica, 55, pp. 251-276.

Gyimah- Brempong, K. 2011. Education and Economic Development in Africa. African Development Review, 23 (2), pp. 219-236.

Hanushek, E. A. 2013. Economic Growth in Developing Countries: The Role of Human Capital. Economics of Education Review, 37, pp. 204-212,

Harvie, C. and Pahlavani, M. 2007. Sources of Economic Growth in South-Korea: An Application of the ARDL Analysis in the Presence of Structural Breaks (1980-2005). The Journal of the Korean Economy, 8(2), pp. 205- 235.

Ighodaro, A. U. and Oriakhi, D. E. 2010. Does the Relationship Between Government Expenditure and Economic Growth follow Wagner's Law in Nigeria. Annals of the University of Petrosani, Econnomics, 10(2), pp.185-198.

Kwack, S. S. and Lee, Y.S. 2006. Analyzing the Korean's Growth Experience: The Application of R \& D and Human Capital-Based Growth Models with Demography. Journal of Asian Economics, 17, pp. 818-831.

Levine, R. and Renault, D. 1992. A sensitivity Analysis of Cross-Country-Growth Regressions. American Economic Review, 82, pp. 942-963.

Lucas, R. E. 1988. On the Mechanics of Economic Development. Journal of Monetary Economics, 2(1), pp.3-42.

Maksymenko, S. and Rabbani, M. 2011. Economic Reforms, Human Capital and Economic Growth in India and South-Korea: A cointegration Analysis. Journal of Economic Development, 36(2), pp. 30-59.

Mankiw, N. G. D, Romer, P. M., and Weil, D.N. 1992. A contribution to the Empirics of Economic Growth. Quarterly Journal of Economics, 107, pp. 407-437.

Maw-Lin, L., Ben-Chieh, L and Ping, P. 1994. Education, Human Capital Enhancement and Economic Development: Comparison Between Korea and Taiwan. Economics of Education Review, 13(4), pp. 275-288.

Mehrara, M. and Musai, M. 2015. The causality between Education and GDP growth in Asian Countries. International Letters of Social and Humanistic Sciences, 50, pp. 28-35.

Mijiyawa, A. G. 2013. Africa's Recent Economic Growth: What are the Contributory Factors? African Development Review, 25(3), pp. 289-302.

Ozekhome, H. O. 2016. Trade Openness, Investment and Economic Growth: Evidence from ECOWAS Countries. West African Financial and Economic Review (WAFER), 16(1), pp. 82-98. 
Ozekhome, H. O. 2017. Economic and Institutional Policies for Sustained Economic Growth for an Oil-Dependent Nigerian Economy in Recession. SAU Journal of Economics, 1(1), pp. 32-48.

Park, C.Y. 2012. Macroeconomic Stabilization Policies for Long-Run Growth: Lessons for Developing Asia. Asia Development Bank (ADB), Paper 2.

Rodrik, D. 1996. Understanding Economic Policy Reform. Journal of Economic Literature, 34 (1), pp. 9-41.

Romer, P. M. 1986. Endogenous Technological Change. The Journal of Political Economy, 98 (5), pp. 871-1208.

Romer, P. M. 1986. Increasing Returns and Long-Run Growth. The Journal of Political Economy, 94 (5), pp. 1002-1037.

Todaro, M.P and Smith, S. C. 2011. Economic development. Tenth ed., Edinburg, England, Pearson Education Limited.

Udah, E. B., 2011. Industrial Development, Electricity Crisis and Economic Performance in Nigeria. European Journal of Economics, Finance and Administrative Sciences, Issue 18.

World Bank. 2016. World Development Indicators Washington D.C: World Bank.

\section{Bio-note}

Hassan Ozekhome holds a B.Sc (Hons) (Economics and Statistics) and M.Sc degree (Economics) of the University of Benin, Benin City, Nigeria. He is at the final stage of his Doctoral Dissertation. His main research interests are in Macroeconomics, Development economics, International economics, Monetary economics, and Applied econometrics. $\mathrm{He}$ has published widely in leading local and reputable international journals, and has participated and presented empirical research and policy papers in many international conferences and workshops. 